\title{
41. CONTROLS ON PHYSICAL PROPERTIES OF PERU CONTINENTAL MARGIN SEDIMENTS AND THEIR RELATIONSHIP TO DEFORMATION STYLES1
}

\author{
Philip R. Hill ${ }^{2}$ and Janice C. Marsters ${ }^{3}$
}

\begin{abstract}
The state of a sediment undergoing deformation depends upon its initial properties at the time of deposition and its subsequent stress history (including diagenetic changes) during burial. Sediment facies classification can be used to determine the variation in initial properties and the relative control this variation has on properties during burial. On the Peru continental margin, three main facies have been identified: laminated diatomaceous mud, massiveto-bioturbated diatomaceous mud, and terrigenous mud. These facies exhibit a gradation in properties, with the laminated diatomaceous mud having very high liquid limit, water content, and shear strength, compared to the terrigenous facies, and with the massive-to-bioturbated facies showing intermediate properties. The properties of the diatomaceous sediments are interpreted to result from a strong particle framework provided by the diatom frustules, which support a high proportion of the sediment load. Dolomitization during burial appears to enhance particle framework strength and results in a heterogeneous sediment column. The development of numerous rupture or fault surfaces, as commonly observed in upper-slope cores from Leg 112, is interpreted as the result of strain-softening during deformation. Scaly cleavage, observed at depth in lower-slope cores, is interpreted to result from strain-hardening behavior that takes place during deformation at greater burial depth.
\end{abstract}

\section{INTRODUCTION}

The physical properties of sediment play an important role in determining the regional and local styles of deformation in a convergent margin. The behavior of deforming sediment is controlled by the consolidation state of the sediment, the drainage conditions, and the stress history of the sediment (Schofield and Wroth, 1968). Determination of sediment physical properties in cores from active margins, where the results of deformation can be observed, provides important insight into the processes and conditions of deformation in these tectonic environments.

During Leg 112, an extensive program was conducted to determine the physical properties of the Peru continental slope sediments. The composition of muddy sediments on the Peru slope is distinctive and greatly influenced by coastal upwelling, which results in high productivity of slope waters and a high flux of organic carbon and diatom frustules to the sea bed (Suess and Thiede, 1983). The physical properties of these sediments are also known to be significantly different from terrigenous muds low in organic content (Keller, 1983).

In this paper, we will review the physical-properties data obtained during shipboard and post-cruise studies, attempt to determine the geologic controls on the physical properties of Peru margin sediments, and relate these properties to observed structural styles of the upper and lower slopes. During Leg 112, a total of 27 holes was drilled at 10 sites on the Peru continental margin (Fig. 1). These sites can be divided into two groups: upper-slope sites, where a series of shallow holes was drilled to investigate the paleoceanographic conditions of the coastal upwelling phenomenon, and lower-slope sites, where deeper holes were drilled to penetrate basement reflectors and reconstruct the uplift and subsidence history of the

\footnotetext{
${ }^{1}$ Suess, E., von Huene, R., et al., 1990. Proc. ODP, Sci. Results, 112: College Station, TX (Ocean Drilling Program).

${ }^{2}$ Hill Geoscience Research, Technology Centre, Suite 220, 70 Neptune Crescent, Dartmouth, Nova Scotia B2Y 4M9, Canada.

${ }^{3}$ Hawaii Institute of Geophysics, University of Hawaii, 2525 Correa Rd., Honolulu, HI 96822.
}

Andean forearc. More physical-properties data were collected from the upper-slope sites, where hydraulic piston coring provided the best samples. In this paper we present new data from Sites $679,680,681$, and 686 from the upper-slope and from Site 685 on the lower-slope (Fig. 1), as well as use shipboard data (Suess, von Huene, et al., 1988) and results from Lee et al. and Marsters and Christian (this volume).

The stratigraphy of the Peru slope is described in detail by the shipboard scientists of Leg 112 (Suess, von Huene, et al., 1988). Cenozoic sedimentation has been dominated by the deposition of organic-rich diatomaceous mud, which was strongly influenced by pronounced coastal upwelling and high productivity conditions that are still characteristic of the region today. The upper- and lower-slope regions have distinctively different tectonic characters. The upper slope has undergone uplift, subsidence, and noncompressional deformation since at least the Miocene, whereas the lower slope consists of an accretionary wedge and is dominated by compressional tectonics (von Huene and Miller, 1988).

Several different deformation styles were observed in seismic profiles and cores. The upper slope is characterized by largescale normal faulting (von Huene and Miller, 1988) and smallerscale faulting observed in cores (for example, Sample 112679D-7H-7, 1-18 cm; see Suess, von Huene, et al., 1988, p. 173), indicating a predominantly brittle deformation. The lower slope is less clearly imaged in seismic profiles, but evidence exists for landward-dipping thrust faults, typical of an accretionary complex. A variety of small-scale tectonic deformation structures, including subvertical planar fabric, extensional faulting, and scaly cleavage, were observed in lower-slope cores. Slump folds are common in both upper- and lower-slope regions.

\section{METHODS}

Original shipboard visual core descriptions and barrel sheets were used to review lithologies and derive a simple facies classification of the slope sediments. Bulk densities obtained with the gamma ray attenuation porosity evaluator (GRAPE, Boyce, 1976) were used to assist in this process, particularly to check bed boundaries, sample locations, and subtle lithologic changes. Bulk densities and water contents of 


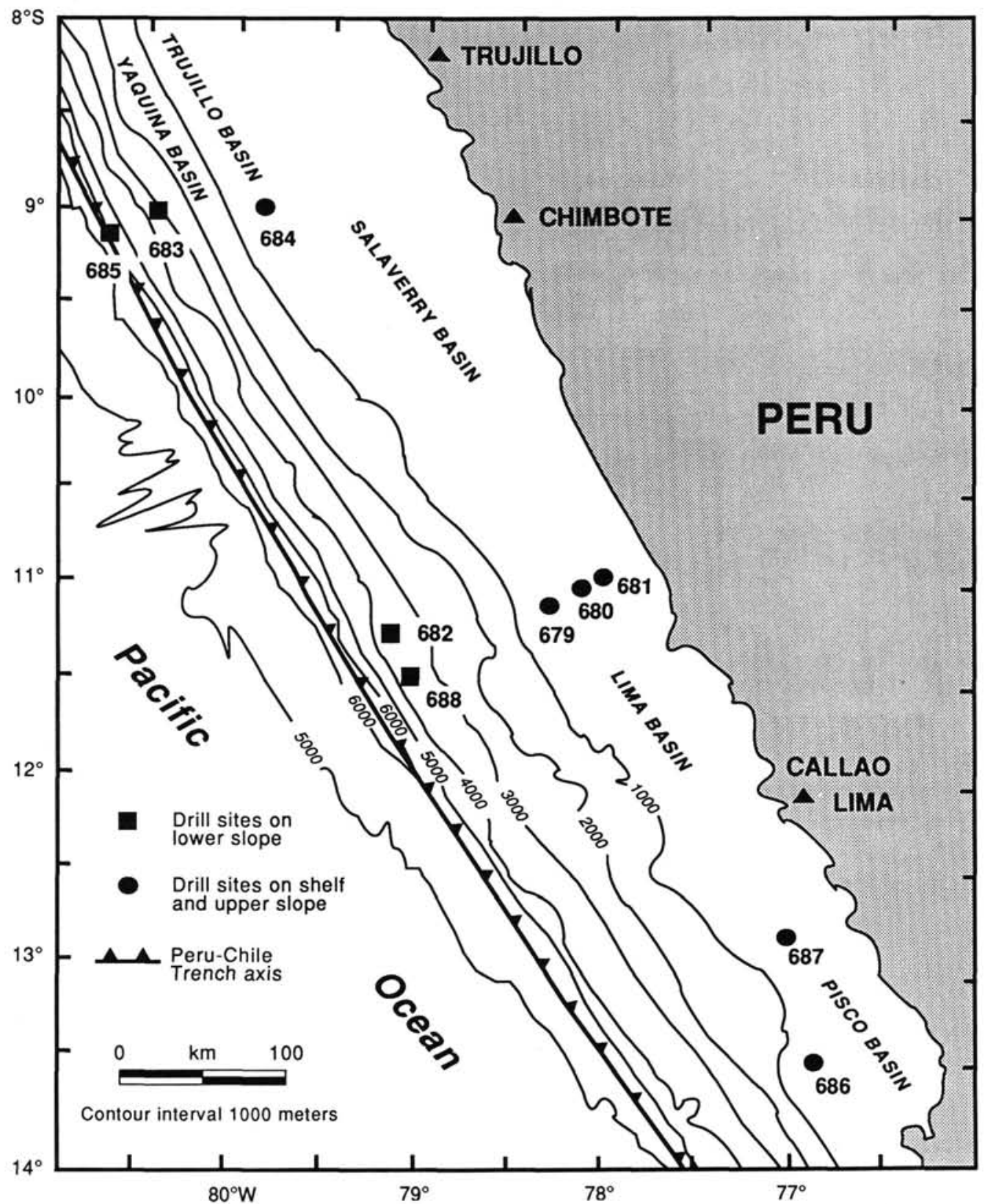

Figure 1. Location map of sites drilled during Leg 112.

samples were measured aboard ship; these values compared favorably with those from the GRAPE over the sample intervals. Water content of the samples was calculated as the ratio of water weight to dry weight of the sample. Undrained shear strength was also measured on board ship using the Wykeham-Farrance miniature vane apparatus.

Samples were taken for Atterberg limits measurements, which were conducted using standard American Society for Testing and Materials (ASTM) methods. Because of the limited volume of material that could be removed from the cores, most samples were smaller than the ASTM-recommended size. The values thus have larger errors than ASTM standards. The two limits measured, liquid and plastic, are, respectively, the upper and lower limits of the range of water content over which a sediment exhibits plastic behavior.
Grain-size analyses were conducted using settling tube and sedigraph. First, the high organic content was removed using a hydrogen peroxide treatment, and then samples were sieved at $53 \mu \mathrm{m}$, and the coarse and fine fractions used in the settling tube and sedigraph, respectively. The data were then remerged to give individual-size spectra at a resolution of approximately 0.2 phi.

\section{GEOLOGIC CONTROLS ON PHYSICAL PROPERTIES}

The state or condition of a marine sediment is dependent on its initial constitutive properties (controlled by factors such as grain size and composition) and the subsequent stress history experienced by the sediment, involving processes of burial, diagenesis, and deformation. In sedimentologic terms, 
the initial properties are also used to define the sediment facies, and thus it is useful to review the different facies observed on the Peru slope and to determine their relationship to sediment physical properties. On the Peru margin, there was much evidence for early diagenesis, and particularly dolomitization of the organic-rich diatomaceous sediment. The effect of dolomitization on physical properties is also reviewed.

\section{Facies Control on Sediment Properties}

The variation of sediment physical properties with lithology was observed in shipboard GRAPE measurements (Fig. 2 ). Where alternations of the main lithologies are present in the core, a corresponding step-like fluctuation of the bulk density is apparent. Figure 3 provides a summary of all the sediment facies encountered during Leg 112. In this study, we deal only with the three most significant facies, based on thickness.

\section{Laminated Diatomaceous Mud}

Finely laminated intervals of dark olive gray diatomaceous mud are common at upper-slope sites (Fig. 3). These muds generally contain more than $20 \%$ diatoms, although some laminae contain in excess of $60 \%$. Some intervals are quite silty, with the silt fraction consisting of quartz, feldspar, and large diatom frustules. The carbonate content of this facies is generally low and consists of poorly preserved foraminifers and nannofossils. The exception to this occurs at horizons where extensive dolomitization took place. Dewatering veins, often associated with microfaulting, are also common within this facies.

\section{Massive to Bioturbated Diatomaceous Mud}

Units of massive to burrow-mottled diatomaceous mud are commonly interbedded with the laminated diatomaceous mud facies in upper-slope cores and predominate in lower-slope cores (Fig. 3). These muds generally have lower diatom and higher terrigenous and foraminifer components, although the range of composition is high.

\section{Terrigenous Sandy Mud and Muddy Sand}

Within the predominantly diatomaceous sequence of the upper slope, intervals of sandy mud and muddy sand with very low contents of diatoms occur. These terrigenous intervals are generally either massive or burrowed and commonly contain concentrations of foraminifers and/or mollusk shell fragments. From smear-slide examination, the coarse fraction of the terrigenous sediments consists primarily of quartz, feldspar, and rock fragments, with smaller amounts of heavy minerals, such as amphiboles and opaques. The fine fraction is dominated by clay minerals.

The three facies can generally be distinguished on the basis of grain size, although considerable overlap occurs. The laminated facies typically exhibits fine-tail size distributions, with dominant sizes in the clay or very fine silt range (Fig. 4A). Some samples have minor modes in the silt range. This silt mode is generally more apparent in the massiveto-bioturbated facies, and the proportion of silt is correspondingly slightly higher (Fig. 4B). The size distributions of the terrigenous facies are distinctively different, are better sorted, and exhibit a coarse silt or sand mode (Fig. 4C).

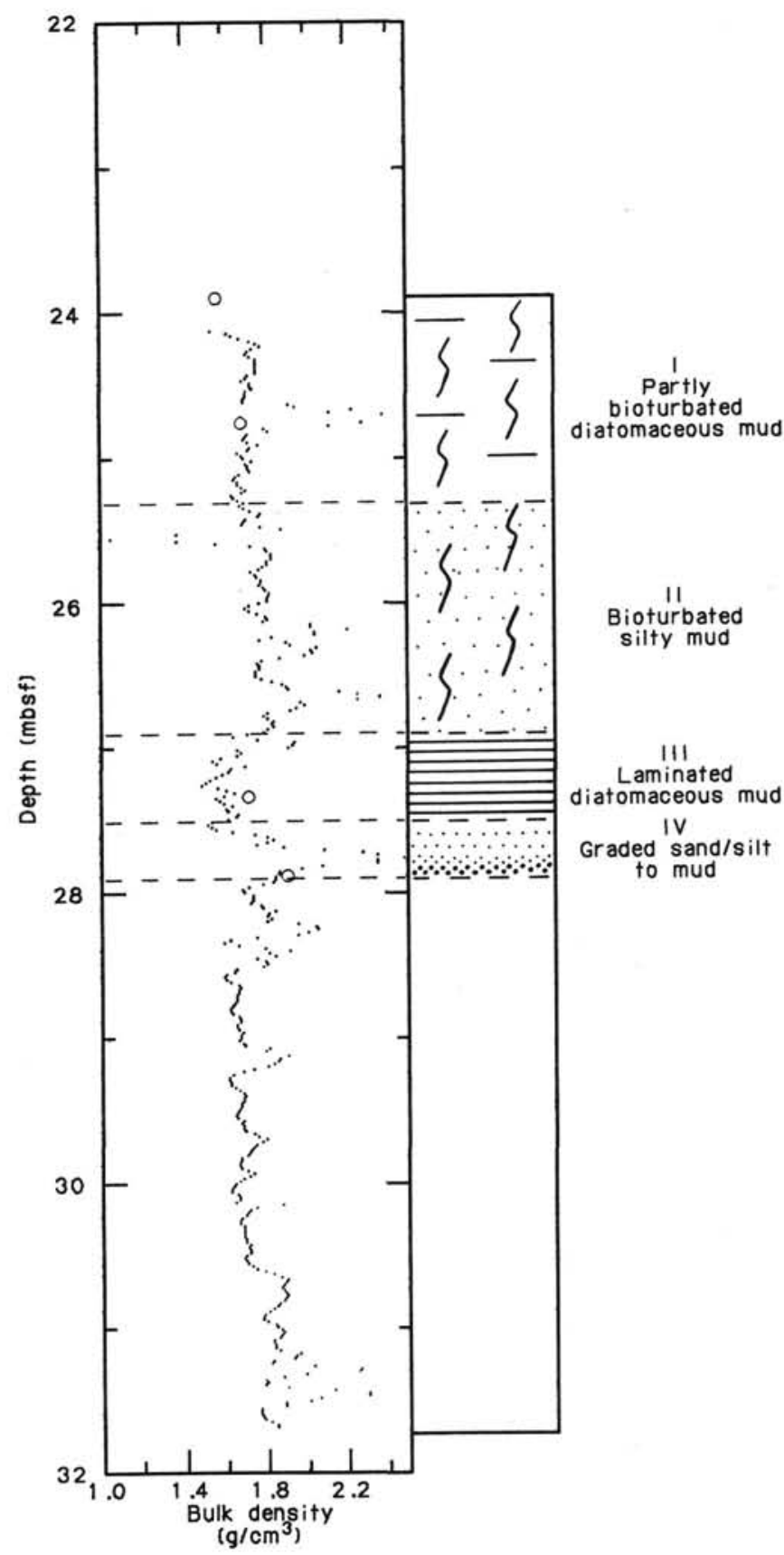

Figure 2. GRAPE bulk density profile from Core 112-686A-4H, showing the relationship between bulk density and lithology.

The laminated and massive-to-bioturbated facies have largely pelagic characteristics, showing little or no sorting. The clay and diatom particles that make up these sediments were deposited under very low-energy conditions. The minor silt mode is not related to dynamic sorting, but probably results from the presence of a larger diatom species. The terrigenous facies is more hemipelagic in character and results from a broader range of dynamic conditions. In this facies, the silt mode is primarily terrigenous and results from sorting under more energetic conditions.

Plastic and liquid limits data for the three facies are shown in the plasticity chart (Casagrande, 1948) of Figure 5. One can 


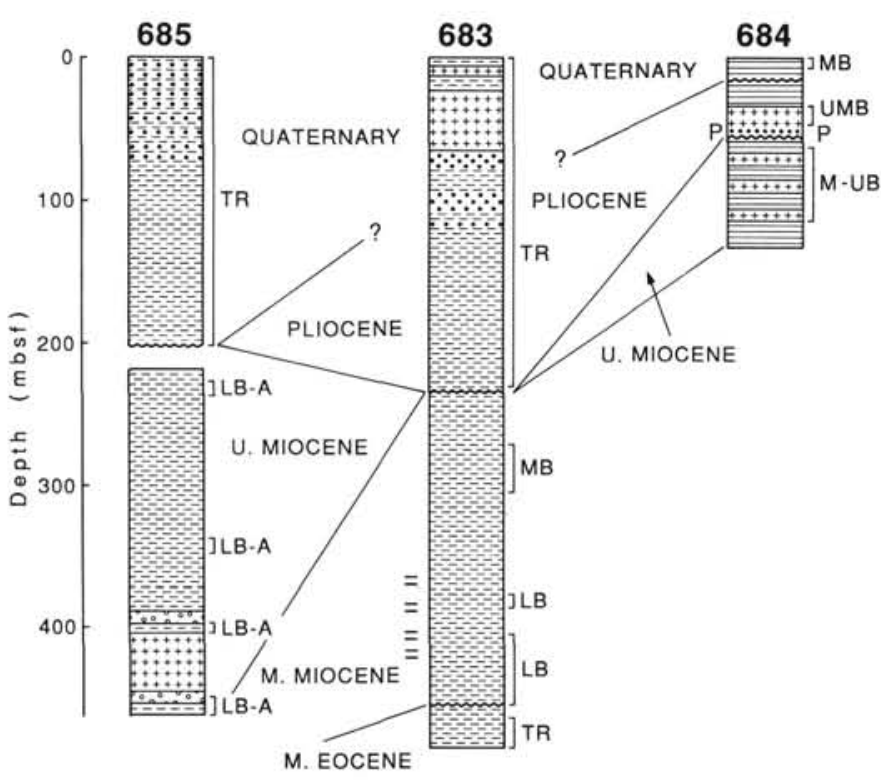

CALCAREOUS SANDSTONES, SILTSTONES, AND commonIy CLAST-SUPPORTED SEDIMENTARY BRECCIA. Clasts of $\because \ldots$ diatomaceous and diatom-bearing mudstones, oozes, micrites 作

BLACK SHALE. Finely laminated with thin fine sand beds.

$=$ INTERVALS WITH SPARSE LAMINATIONS

mm UNCONFORMITY

P PHOSPHATIC GRAVEL

Figure 3. Summary of sediment facies distribution in Leg 112 drill holes.

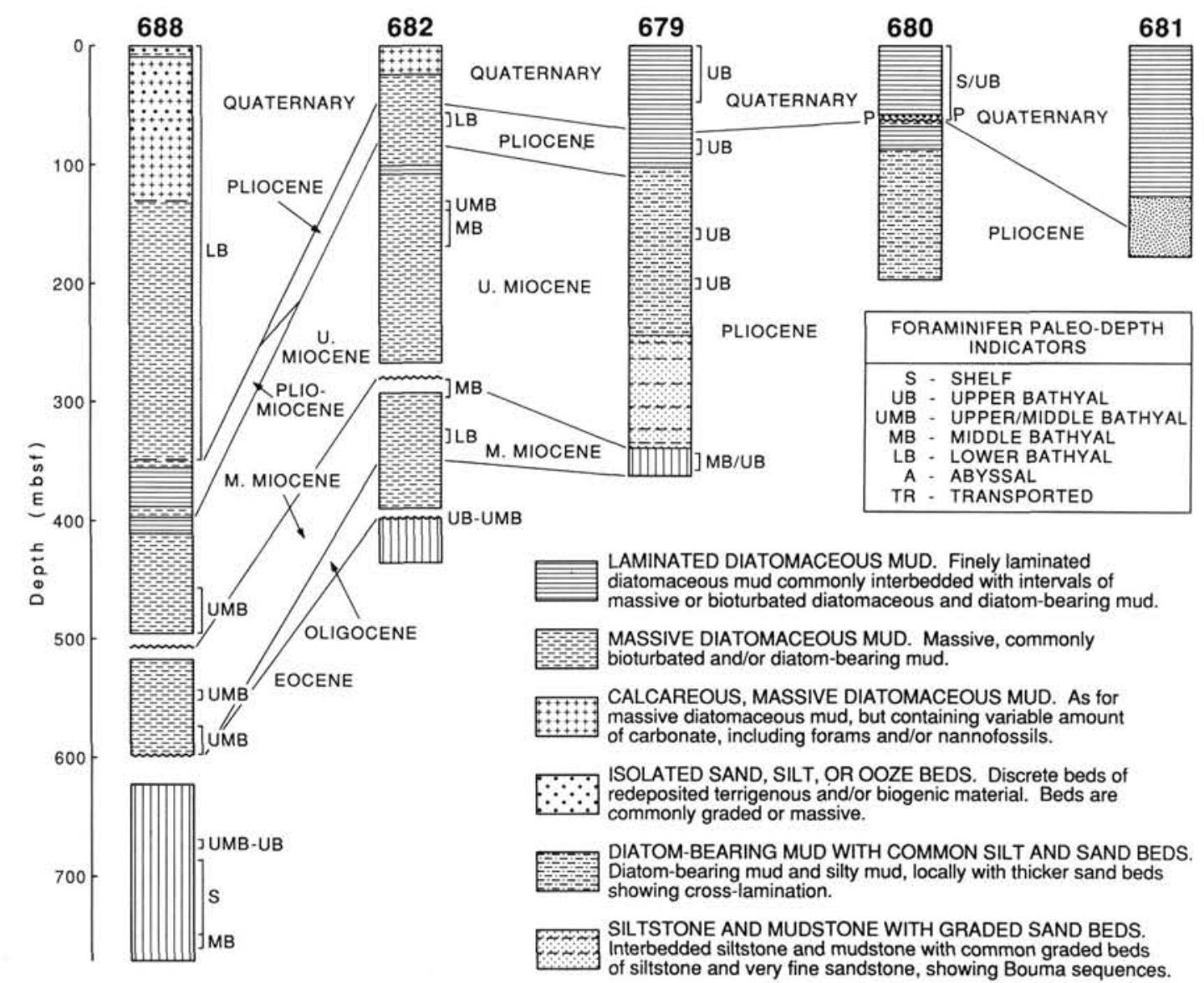



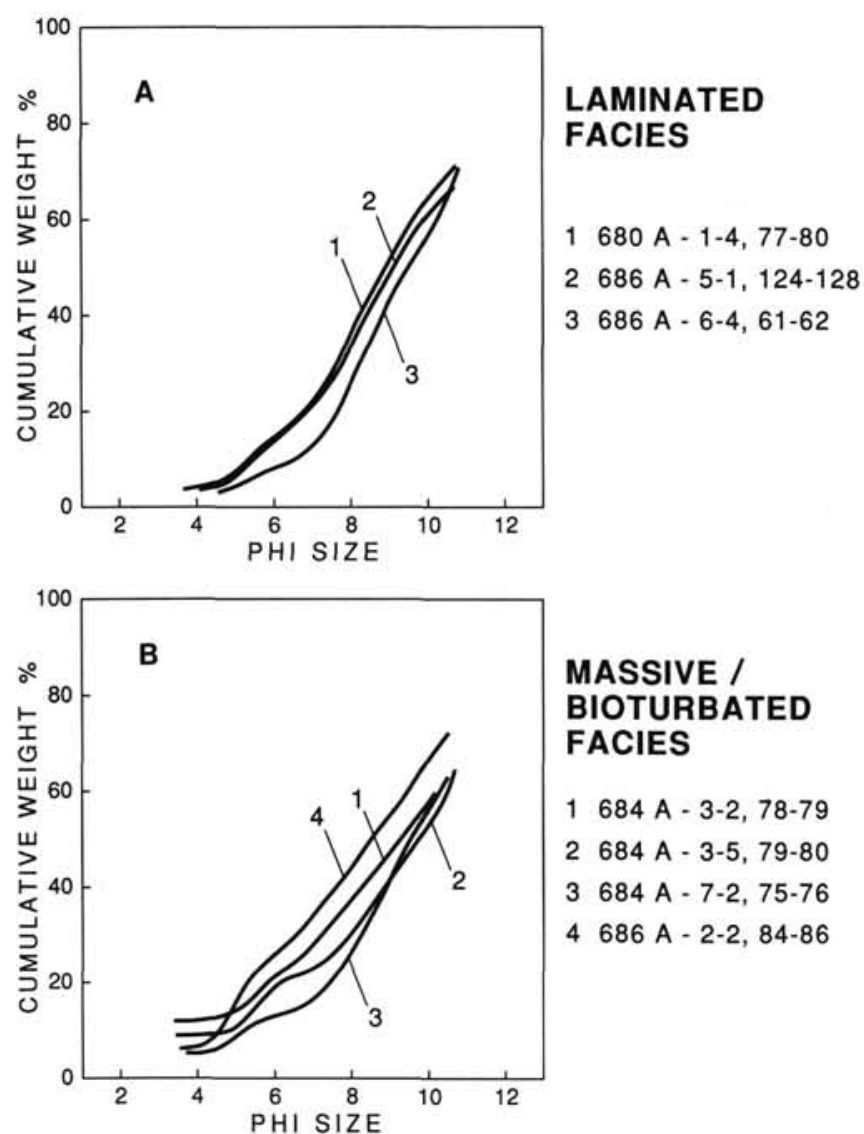

\section{MASSIVE / BIOTURBATED FACIES}

1684 A $-3-2,78-79$

$2684 \mathrm{~A}-3-5,79-80$

$3684 \mathrm{~A}-7-2,75-76$

4686 A - $2-2,84-86$

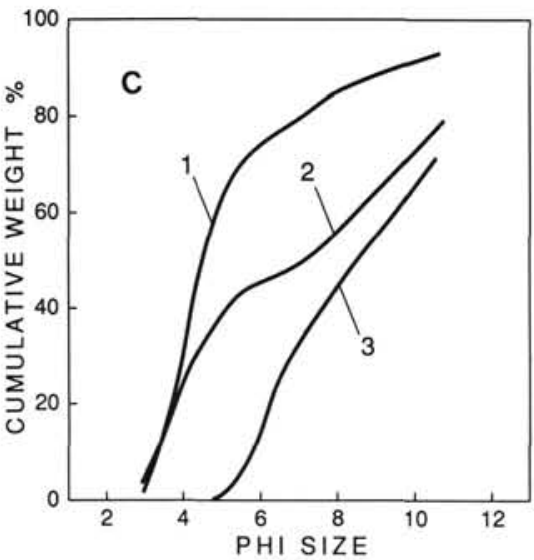

\section{TERRIGENOUS FACIES \\ 1680 A - 3-6, 106-109 \\ 2680 A $-4-6,106-109$ \\ 3680 A $-7-4,57-60$}

Figure 4. Representative cumulative grain-size distribution curves for the three facies described here. A. Laminated facies. B. Massiveto-bioturbated facies $\mathrm{C}$. Terrigenous facies.

see that the three main facies plot as overlapping, but easily discriminated, fields. The terrigenous sandy mud has nearnormal characteristics of low-to-medium plasticity silts and clays. The more diatomaceous sediments of the massiveto-bioturbated mud and the laminated diatomaceous mud have progressively more extreme values of liquid limit, while maintaining low values of plasticity index, thus falling well below the "A-line" (Fig. 5). Sediments plotting in this area of the plasticity chart are generally classified as inorganic silt (micaceous or diatomaceous) or organic clay (Das, 1983, p. 35-36). Samples from the lower-slope (Hole 685A), classified as massive-to-bioturbated facies, have liquid limits at the

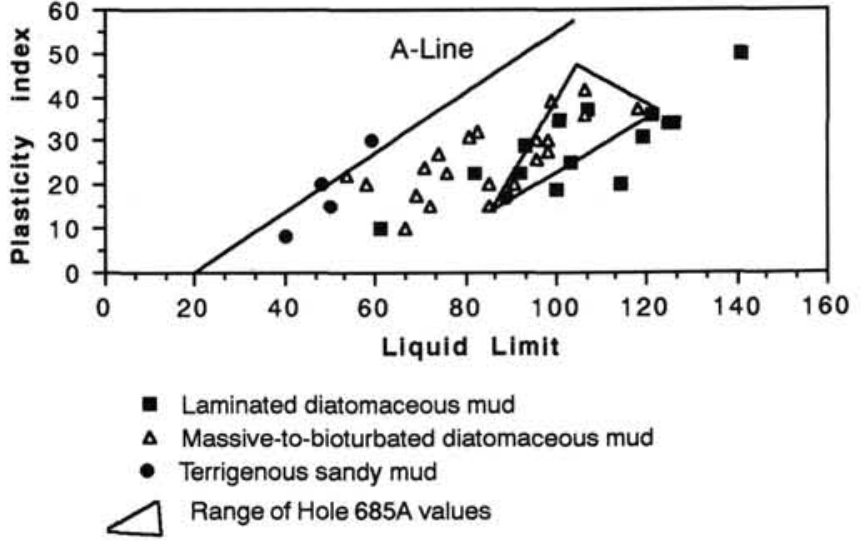

Figure 5. Plasticity chart of samples from Sites 679, 682, 685, and 686.

upper end of the range for this facies. They overlap significantly with the field of the laminated facies.

Similar results were obtained on Peru margin sediments by Busch and Keller (1981) and Lee et al. (this volume). These scientists found that liquid and plastic limits can be correlated with the measured organic carbon content of the sediments, although the correlation is weaker for higher values of each limit. However, we suspect that the high diatom content plays a significant role in determining the plasticity of these sediments. A review of smear-slide data from Leg 112 suggests that there are grounds for this interpretation. For example, the relatively high values of liquid limit and plasticity index, shown by the massive-to-bioturbated facies from Hole $685 \mathrm{~A}$ correspond to higher estimates of diatom contents from smear slides. However, a more accurate quantification of the diatom content for correlation with the Atterberg limits data has not been possible.

The water content of the Peru margin sediments also shows a dependence on facies (Fig. 6). In general, the water content is highest in the laminated facies and lowest in the terrigenous facies, with the massive-to-bioturbated facies showing intermediate values. In the laminated facies data, it is apparent that water content values lie well above the range of plastic behavior defined by the plastic and liquid limits. Water contents of the massive-to-bioturbated and terrigenous facies generally lie within the overall range of plasticity. These results imply that the fabric of the laminated sediments has sufficient strength to support the sediment and to maintain high water contents without the occurrence of significant consolidation. Potentially, if this sediment were remolded, whereby the fabric was destroyed, this sediment might flow (Busch and Keller, 1981).

Neither the laminated nor massive-to-bioturbated facies exhibit any significant reduction in water content with depth over the top 100 to $200 \mathrm{~m}$ of burial. At Site 686 (Fig. 6), the trend, if any, is toward higher water contents at depth. This trend does not extend to greater depths: at the lower-slope Site 685 , the upper $100 \mathrm{~m}$ has a variable water content profile, but below $100 \mathrm{~m}$, the water content clearly decreases with depth (Fig. 7).

Bulk density profiles show similar characteristics (Fig. 8). Over the top $50 \mathrm{~m}$, the laminated facies shows consistently lower density than the massive-to-bioturbated facies. The terrigenous facies has a higher density than either of the diatomaceous facies. These values remain almost constant with depth, reflecting the water content profiles.

Shear strength is also controlled to some extent by facies. Figure 9 depicts downhole strength profiles for the two 


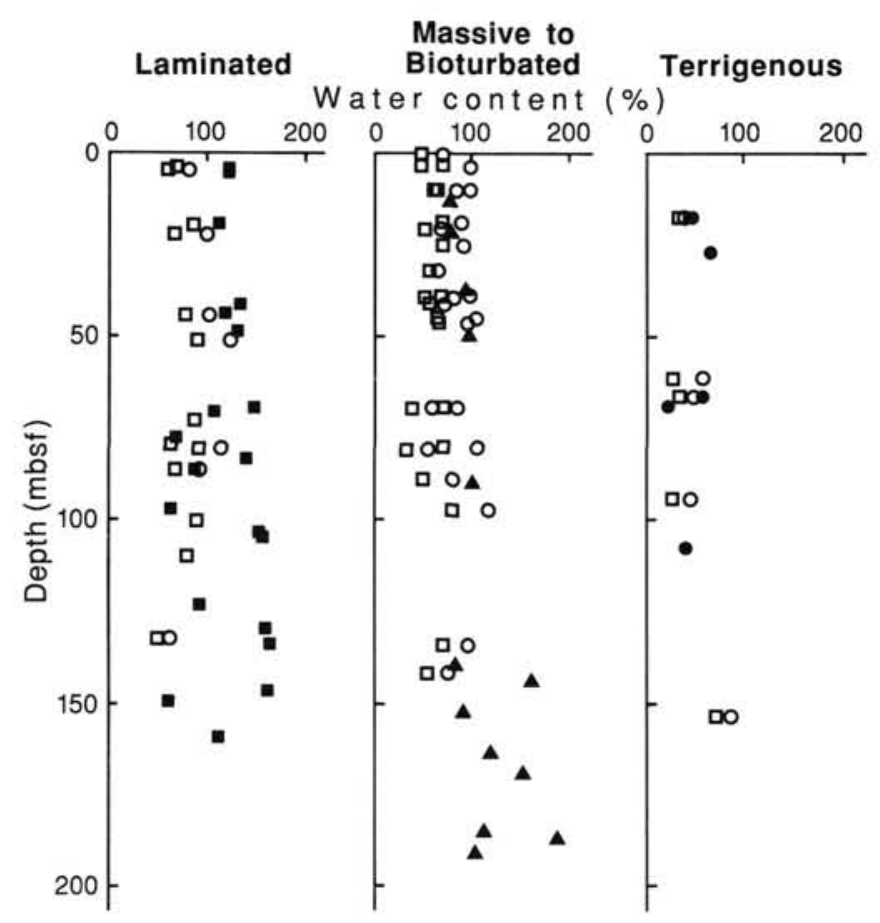

Figure 6. Downhole variation of water content in Hole 686B by facies. Open circles and open squares correspond to liquid and plastic limit, respectively; solid symbols represent water content.

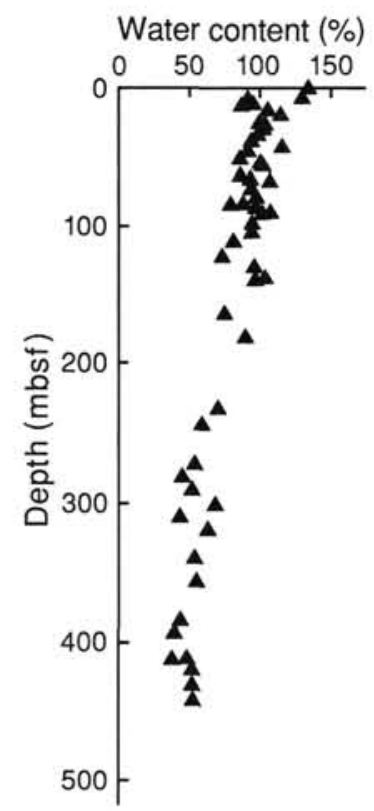

Figure 7. Downhole variation of water content in Hole 685A. The massive-to-bioturbated facies predominates in this hole. Note that water content gradually decreases with depth below approximately $100 \mathrm{~m}$.

diatomaceous facies, determined with the shipboard shear vane apparatus at Site 686. Insufficient data exist to show a similar plot for the terrigenous facies. Both facies show a modest increase in strength with depth over the top $200 \mathrm{~m}$, which is apparently independent of density or water content. The increasing shear strength is more apparent in the laminated facies. The peak shear strength of the diatomaceous facies is very high compared to terrigenous sediment from

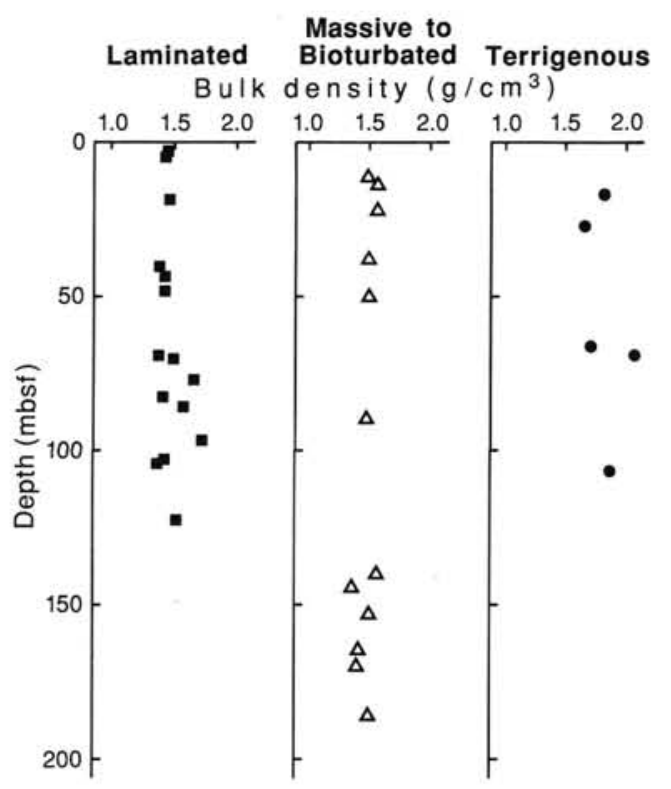

Figure 8. Downhole variation in bulk density in Hole 686B by facies. Note that the density does not systematically increase with depth.

other continental margins. For comparison, the laminated facies shows a peak strength of approximately $50 \mathrm{kPa}$ in the top few meters of Hole 686B, whereas on the eastern U.S. continental margin, strengths rarely exceed $20 \mathrm{kPa}$ at lower water contents and over the same burial depths (Keller et al., 1979).

\section{Effect of Dolomitization on Physical Properties}

Dolomite was detected in Peru margin sediments in two main forms: (1) as hard cemented nodules or beds several centimeters thick, and (2) as dolomite rhombs observed in smear slides. The distribution of both forms varied from site to site, but in upper-slope sediments they occurred commonly within a few meters of the sea bed (Suess, von Huene, et al., 1988). Generally, sampling for physical property measurements avoided intervals where obvious nodular dolomitization occurred. However, there is evidence that the presence of microcrystalline dolomite has an important effect on the sediment properties elsewhere. Three examples are used to illustrate this possible relationship.

At Site 686, the average water content remains relatively constant to approximately $100 \mathrm{~m}$, but below this depth it begins to fluctuate widely and reaches extreme values near $200 \%$ (Fig. 6). This change corresponds closely to the presence of numerous cemented dolomite beds and nodules, as well as to an increase in dolomite rhombs observed in smear slides (see "Site 686" chapter in Suess, von Huene, et al, 1988). Although smear-slide estimates can only be used qualitatively, the increase at this level from trace amounts to estimated proportions as high as $5 \%$ is significant. The corresponding shear strength profile shows that shear strengths increase only slightly over this interval (Fig. 9).

A more significant increase in shear strength occurs in Hole 686B between 20 and $40 \mathrm{~m}$ (Fig. 9A). Over this short interval, two shear strength measurements gave values greater than 100 $\mathrm{kPa}$, compared with about 50 to $70 \mathrm{kPa}$ above and below. This interval is also characterized by above trace amounts of dolomite observed in smear slides.

A third example of the effect of dolomitization on physical properties occurs at Site 680 . Here, only traces of dolomite were observed in smear slides over the top $30 \mathrm{~m}$ of the 


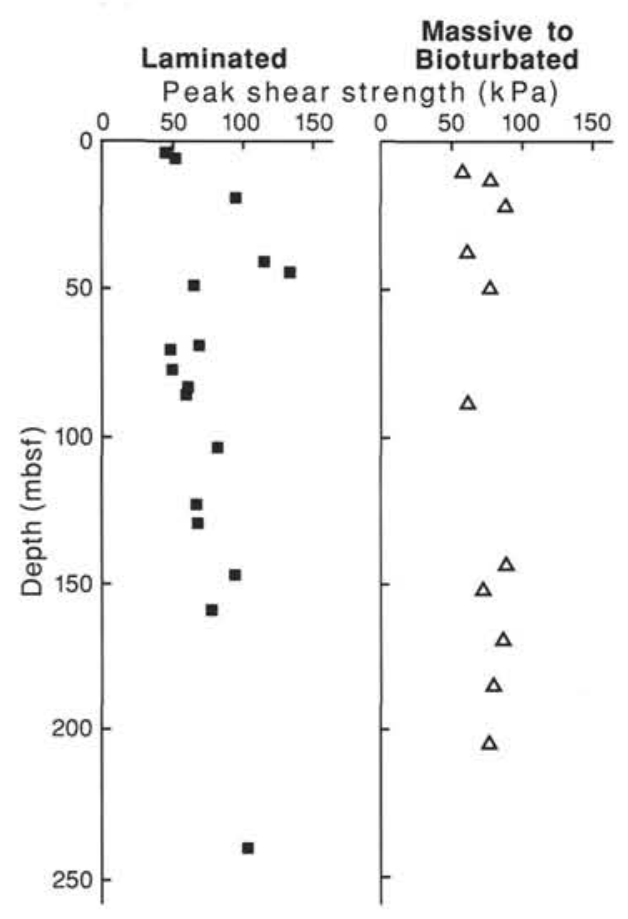

Figure 9. Downhole variation of vane shear strength for the laminated and massive-to-bioturbated facies in Hole 686B. Note high values between 20 and $40 \mathrm{~m}$, which may be related to dolomitization.

sediment column, but below $30 \mathrm{~m}$, numerous cemented dolomite beds are present and smear slide estimates of dolomite rhombs from adjacent sediments are as high as $30 \%$. The profile of shear strength for this site shows a slight but steady increase in shear strength from the sea bed to a depth of $30 \mathrm{~m}$. From 30 to $70 \mathrm{~m}$, the profile fluctuates greatly, from values generally less than $100 \mathrm{kPa}$ to values as high as $200 \mathrm{kPa}$ (Fig. 10).

The association of highly variable physical properties with dolomite observed in smear-slide analysis strongly suggests that the presence of microcrystalline dolomite may have had an influence on physical properties, even when cementation cannot be directly observed. In all the above cases, phosphatic nodules are also present in association with dolomite. It is unlikely, however, that the phosphate influences physical properties, except locally. In contrast to dolomite, phosphatic minerals were rarely observed in smear slides, except where actual nodules were sampled. The phosphatic nodules are probably related to locally concentrated sources of phosphate such as fish remains, whereas the dispersed dolomite is related to geochemical gradients through the sediment column. Thus, dolomitization is likely to be the more important diagenetic influence on physical properties of the diatomaceous sediments.

\section{DISCUSSION}

The data presented illustrate that the facies or "initial constitutive properties" do exert some control on the state of sediments on the Peru margin. The diatomaceous sediments have several notable characteristics that differ markedly from terrigenous sediments found on other continental margins. The combination of high peak shear strength, high liquid limit, and high water content, commonly higher than the liquid limit, suggests that the particle framework strength of the sediment is high. A possible cause of this framework strength is that silica diatom frustules form an interlocking structure that

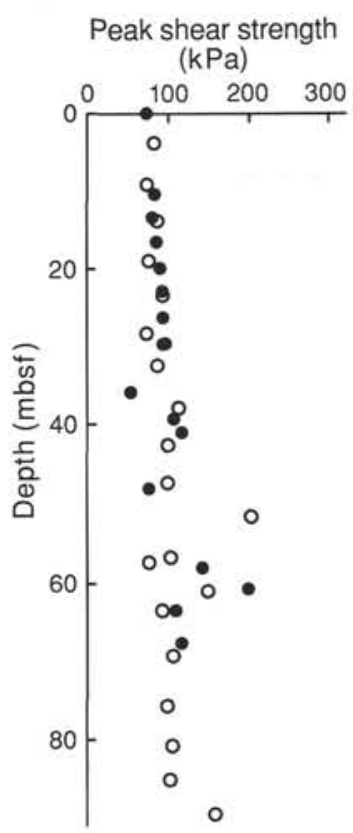

Figure 10. Downhole variation of vane shear strength at Site 680 . The change from relatively uniform to widely fluctuating strength at approximately $30 \mathrm{~m}$ illustrates the possible effect of dolomitization, which is prevalent below $30 \mathrm{~m}$ at this site.

supports a high proportion of the sediment load. This effect may be further enhanced by the high organic carbon content, which correlates positively with diatom content (Lee et al., this volume). Failure of the diatomaceous sediment probably depends, in large part, on the particle framework strength and would require excess pore pressures that were higher than the estimated lithostatic stress.

If no other influences were present, the constitutive properties described above would control the consolidation and resultant properties during burial. Under such "rest state" conditions, terrigenous muds generally show a downhole decrease in water content and an increase in bulk density and shear strength. The diatomaceous sediment of the Peru margin does not behave in this way. For example, water content and bulk densities do not change systematically through the top $100 \mathrm{~m}$ of the sediment column, but remain, on average, relatively constant (Figs. $6,7,8$ ). This behavior was noted at every site drilled during Leg 112 , with the possible exception of Site 688 .

One cannot be absolutely sure whether this behavior is related to the primary characteristics of diatomaceous sediments or to subsequent diagenesis. However, it seems likely that the strength of the diatom framework is high enough to support the sediment load to considerable depth, thus maintaining open pore spaces and allowing high water contents to exist. A moderate degree of dolomitization would probably enhance the particle framework strength by providing extra interparticle bonding. This does not appear to be critical, as the behavior is present in holes where dolomitization does not occur extensively. Extensive dolomitization is likely to close pore spaces, and high water contents could not exist. Consolidation tests on sediments from the upper $100 \mathrm{~m}$ of several sites indicate that they are over-consolidated (Lee et al., this volume; see also Keller, 1983), although the fabric strength may dominate behavior in these tests, so that the existence of excess in-situ pore pressures cannot be estimated.

In an attempt to relate unlithified sediment properties to deformation structures in active margins, Brandon (1984) 


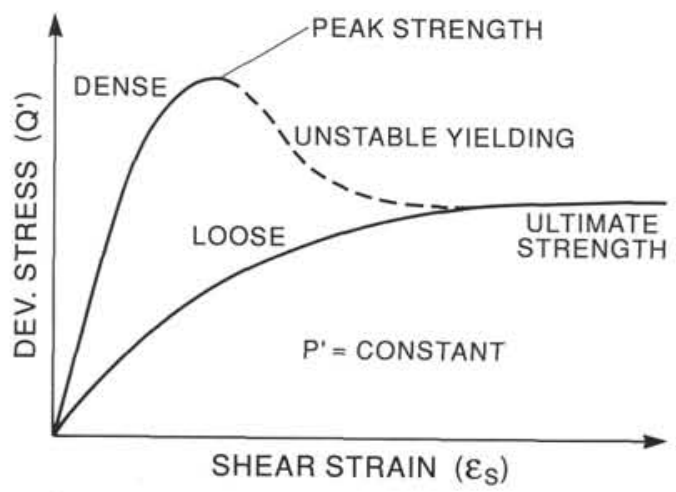

Figure 11. Schematic illustration of the two types of deformation behavior of sediments. See text for explanation.

proposed a model to predict deformation style based on the elastic-plastic properties of sediments experiencing tectonic stresses. Brandon's analysis was based on the concept of critical-state soil mechanics, where the stress path during deformation depends on whether the initial state of the sediment is less dense or more dense than the ultimate, fully remolded condition (or critical state) of the sediment (Schofield and Wroth, 1968). Two main types of behavior can be predicted (Fig. 11): (1) strain hardening, characteristic of sediments looser than the critical state, which occurs when sediment strength increases and void ratio (pore volume/solid volume) decreases during deformation to some ultimate strength and void ratio (contractive behavior), at which point, it continues to deform without further change in volume; and (2) strain softening, characteristic of sediments denser than the critical state, which occurs when the sediment is characterized by a peak strength greater than its ultimate strength, and therefore strength decreases and void ratio increases (dilative behavior) with continued deformation. In undrained, or no-volume-change, conditions, strain-hardening sediments will respond with positive excess pore pressure, and strainsoftening sediments will respond with negative excess pore pressure.

Strain hardening promotes stable homogeneous deformation as weaker regions become stronger, and the deformation is spread homogeneously through the sediment. Strain-softening results in unstable deformation, as strain occurs in weaker zones that are further weakened by the deformation. While these zones weaken, the surrounding stronger sediment
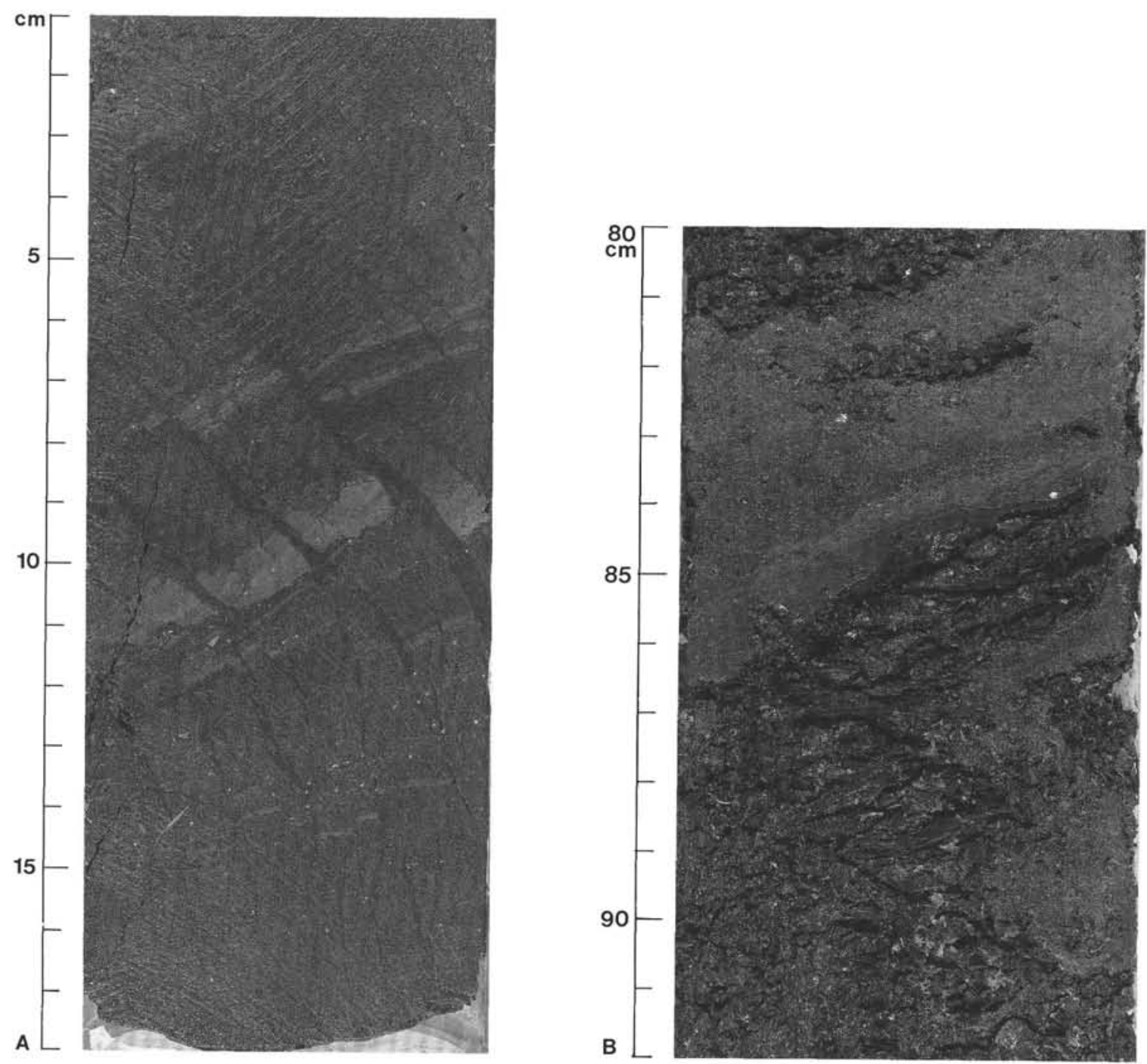

Figure 12. A. Example of small-scale faulting and associated dewatering veins from the upper slope (112-679D-7H-7, 1-18 $\mathrm{cm})$. B. Example of scaly cleavage from deeply buried sediments on the lower slope $(112-685 \mathrm{~A}-39 \mathrm{X}-3,80-91 \mathrm{~cm})$. 
is unloaded, releasing elastic strain energy, which causes a propagation of a rupture in the weakened zone. This latter form of deformation thus results in the formation of discrete faults. These two types of behavior occur theoretically under both drained and undrained conditions (Brandon, 1984).

The numerous examples of brittle deformation observed in upper-slope cores (Fig. 12A) suggest that strain-softening deformation has occurred. It would appear that the particle framework and resultant high peak shear strength give the sediment denser than critical properties, resulting in dilative behavior, despite its high water content. Support for this behavior can be found in undrained triaxial tests in which a relatively high degree of dilatant behavior was observed for shallow sections of Holes 679C and 681C (Lee et al., this volume, Figs. 7 and 9). Dilation is also more apparent in tests conducted at relatively low confining pressures (Lee et al., this volume, their Figs. 7, 8, and 9). The heterogeneous strength profile, which develops as dolomitization takes place, would further enhance the strain-softening behavior, creating weak areas where deformation might initially be concentrated.

In many cases of faulting in the upper-slope holes, the fault planes are filled with fine-grained diatomaceous mud, indicating that dewatering occurs during rupture of the sediment. This evidence appears to contradict the hypothesis that dilation is occurring during deformation, as water should not be released. However, both Brandon (1984) and Rice (1975) argued that local variations of pore pressure should occur at the failure zone. Thus, the presence of vein-filling may not be an indication of significant dewatering of the whole sediment mass.

A different deformation style, principally scaly cleavage, is common in deeply buried sediments from Sites 682 and 685 on the lower slope (Fig. 12B). Brandon (1984) suggested that scaly cleavage results from the more homogeneous deformation characteristic of strain hardening. The composition and plastic properties of the lower-slope sediments are basically similar to upper-slope sediments, and although there appears to be less visible dolomitization in the lower-slope holes, dolomite has been recorded in smear-slide descriptions at significant levels. This evidence seems to indicate that both strain-hardening and strain-softening behaviors occur in diatomaceous sediments of similar composition. Strain-hardening behavior occurs at greater burial depths, where the confining pressure is higher. This is consistent with triaxial tests conducted at higher confining pressures, where contractive behavior of the sediment is more pronounced (Lee et al., this volume). A sediment having a strong particle framework can change with increasing stress from predominantly strainsoftening (dilative) behavior to strain-hardening (contractive) behavior, and thereby cross the critical state line (Fig. 13). The relatively small decrease in void ratio with increasing stress is observed in consolidation test results on Leg 112 samples (Marsters and Christian, this volume). The strong particle framework, by keeping the void space open during burial, therefore influences the style of deformation observed in these diatomaceous sediments.

If the above interpretations in deformation behavior are correct, there are important implications to the development of accretionary prisms, where sediment of this kind is being deformed. At low confining pressures, near the toe of the accretionary prism and in the upper few hundred meters of the sediment column, strain-softening deformation may be expected. Further into the accretionary prism, and at depth, strain-hardening deformation will predominate. A corresponding zonation of structures within individual prism slices or superposition of shallow vs. deeply formed structures might

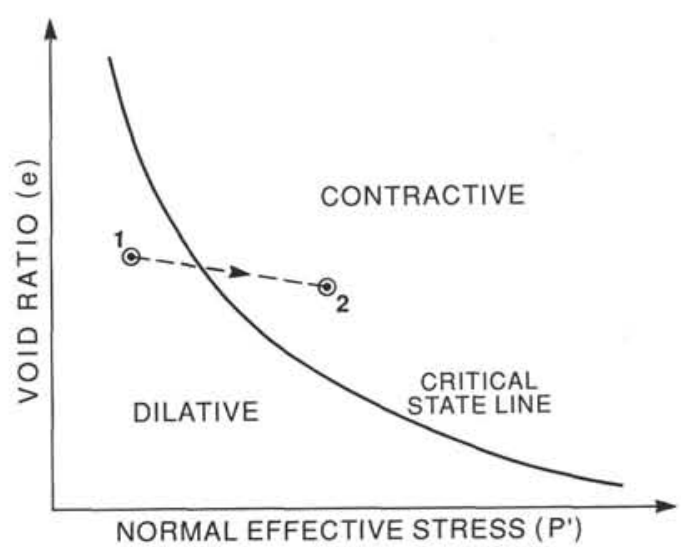

Figure 13. Schematic illustration of the state of diatomaceous sediment at low stress or shallow burial depth (1) and at higher stresses or deeper burial depths (2). The strong particle framework of the sediment allows the void ratio to remain high at higher stress values.

be predicted. Extensive dewatering of the accretionary prism, as observed at other active margins (e.g., Bray and Karig, 1985), may be inhibited in the upper part of the sediment column, but may dominate in the more deeply buried sediment during the initial stages of deformation.

Although the strain-softening behavior results from the strong particle framework of the diatomaceous sediment of the Peru margin, it is possible that diagenetic strengthening of sediment may produce similar behavior. Therefore, this process may not be restricted to margins where this type of sediment occurs.

To test these interpretations and better understand the relationship among sediment properties, deformation style, and diagenesis, several detailed studies will be required. Microfabric analysis of diatomaceous mud before and after deformation should help to demonstrate how the particle framework behaves. Better quantification of dolomitization and its effect on strength might determine the levels of dolomitization that cause strengthening of the sediment framework. Further triaxial and consolidation testing of these sediments at various confining pressures, to build on the work of Lee et al. (this volume) and Marsters and Christian (this volume), should indicate under what burial conditions the particle framework strength breaks down. In-situ measurement of pore pressures should better define realistic stress states and substantially improve our understanding of deformation processes.

\section{CONCLUSIONS}

1. Undeformed near-surface diatomaceous sediments of the Peru margin have several notable properties, including high peak shear strength, high liquid limits, and high water contents, often higher than liquid limits. These properties suggest that the particle framework strength of these sediments is high.

2. Dolomitization of the diatomaceous mud increases shear strength by enhancing the strength of the particle framework bonding. Dolomitization also produces a heterogeneous sediment column in terms of shear strength.

3. During deformation at low confining pressures, these sediments are likely to develop strain-softening, which leads to the development of discrete rupture (fault) surfaces, as commonly observed at upper-slope sites.

4. The development of more homogeneous deformation, such as the development of scaly cleavage at greater burial depth, suggests that strain-hardening behavior is more com- 
mon in deeper parts of the accretionary complex. This suggests that the particle framework strength is constant and does not increase with consolidation.

\section{ACKNOWLEDGMENTS}

Participation during Leg 112 and much of the sample analysis for this paper were supported by the Geological Survey of Canada. Manuscript preparation was supported by a Natural Sciences and Engineering Research Council (Canada) Operating Grant to P. R. Hill, while an Honorary Research Associate of Dalhousie University. We thank Kate Moran, Homa Lee, and Robert Kayen for reviewing the manuscript, as well as Kate, Harold Christian, and Don Gillespie for many hours of discussion.

\section{REFERENCES}

Boyce, R. E., 1976. Definitions and laboratory techniques of compressional sound velocity parameters and wet water content, wet bulk density and porosity parameters by gravimetric and gamma ray attenuation techniques. In Schlager, S. O., Jackson, E. D., et al., Init. Repts. DSDP, 33: Washington (U.S. Govt. Printing Office), 931-958.

Brandon, M. T., 1984. Deformational processes affecting unlithified sediments at active margins: a field study and a structural model (Unpubl. Ph.D. dissert.). University of Washington.

Bray, C. J., and Karig. D. E., 1985. Porosity of sediments in accretionary prisms and some implications for dewatering processes. $J$. Geophy. Res., 90:768-778.

Busch, W. H., and Keller, G. H., 1981. The physical properties of Peru-Chile continental margin sediments-the influence of coastal upwelling on sediment properties. J. Sediment. Petrol, 51:705719.
Casagrande, A., 1948. Classification and identification of soils. Am. Soc. Civil Engrs. Trans., 113:901-931.

Das, B. M., 1983. Advanced Soil Mechanics: New York (McGraw Hill).

Keller, G. H., 1983. Coastal upwelling, its influence on the geotechnical properties and stability characteristics of submarine deposits. In Suess, E., and Thiede, J. (Eds.) Coastal Upwelling: Its Sediment Record, Vol. 1: New York (Plenum Press), 181-199.

Keller, G. H., Lambert, D. N., and Bennett, R. H., 1979. Geotechnical properties of continental slope deposits Cape Hatteras to Hydrographer Canyon. In Doyle, L. J., and Pilkey, O. H. (Eds.), Geology of Continental Slopes. Soc. Econ. Paleontol. Mineral. Spec. Publ., 27:131-151.

Rice, J. R., 1975. On the stability of dilatant hardening for saturated rock masses. J. Geophy. Res., 80:1531-1536.

Schofield, A., and Wroth, P., 1968. Critical State Soil Mechanics: New York (McGraw-Hill).

Suess, E., and Thiede, J., 1983. Responses of the sedimentary regime to coastal upwelling. In Suess, E., and Thiede, J. (Eds.), Coastal Upwelling: Its Sediment Record, Vol. 1: New York (Plenum Press).

Suess, E., von Huene, R., et al., 1988. Proc. ODP, Init. Repts., 112: College Station, TX (Ocean Drilling Program).

von Huene, R., and Miller, J., 1988. Migrated multichannel seismic reflection records across the Peru continental margin. In Suess, E., von Huene, R., et al., 1988. Proc. ODP, Init. Repts., 112: College Station, TX (Ocean Drilling Program), 109-119.

Date of initial receipt: 16 January 1989

Date of acceptance: 3 August 1989

Ms 112B-168 